\section{Bheemamyces, a new genus of the family Asterinaceae (Ascomycetes)}

\author{
V.B. Hosagoudar ${ }^{1}$, A. Sabeena ${ }^{2}$ \& M.C. Riju ${ }^{2}$ \\ 1,2 Tropical Botanic Garden and Research Institute, Palode, \\ Thiruvananthapuram, Kerala 695562, India \\ Email: ${ }^{1}$ vbhosagoudar@rediffmail.com
}

During a survey of foliicolous fungi in the Western Ghats region of Kerala State, authors came across infected leaves of Argyreia nervosa, collected from the Malabar Botanic Garden, Kozhikode. The fungus revealed brown mycelium with the lateral appressoria and stellately dehisced orbicular thyriothecia. These are the characters of the genus Asterina. In addition to these typical characters, the mycelia originated from the main hyphae, lifted slightly above the host surface, appearing like a 'whip', possessing intercalary and sub intercalary or sub lateral appressoria, making it distinct from the genus Asterina. Because of the intercalary appressoria, it can not be placed under the genus Asterolibertia because it also possesses the characters of the genus Asterina, having lateral appressoria (Muller \& Arx 1962; Arx \& Muller 1975; Hosagoudar et al. 2001). Hence, to accommodate such fungi, the genus Bheemamyces is proposed here. This is a transitional genus between the genera Asterina and Asterolibertia.

Date of publication (online): 26 November 2010

Date of publication (print): 26 November 2010

ISSN $0974-7907$ (online) | 0974-7893 (print)

Editor: Richard Mibey

Manuscript details:

Ms \# 02583

Received 23 September 2010

Finally accepted 09 November 2010

Citation: Hosagoudar, V.B., A. Sabeena \& M.C. Riju (2010) Bheemamyces, a new genus of the family Asterinaceae (Ascomycetes). Journal of Threatened Taxa 2(12): 1323-1324.

Copyright: () V.B. Hosagoudar, A. Sabeena \& M.C. Riju 2010. Creative Commons Attribution 3.0 Unported License. JoTT allows unrestricted use of this article in any medium for non-profit purposes, reproduction and distribution by providing adequate credit to the authors and the source of publication.

Acknowledgements: We thank Dr. A. Subramoniam, Director, Tropica Botanic Garden and Research Institute, Palode for the facilities and Dr. R. Ansari, Managing Director (Retd.), Malabar Botanic Garden, Kozhikode for providing the facilities during the collection trip.

\section{OPEN ACGESS I FREE DOWNLOAD (C) (i) (4)}

\section{Bheemamyces}

V.B. Hosagoudar, gen. nov.

The name Bheema is derived from the brave personality of Pandavas from the epic Mahabharata.

Coloniae foliicolae, brunneae, ramosae, septatae, appressoria uterque intercalaris vel lateralis, saepe hyphae formans annulus. Thyriothecia orbicularis, stellatim dehiscentes ad centre; asci globosi, octospori; ascosporae conglobatae, brunneae, uniseptatae.

Colonies foliicolous, brown, branched, septate, appressoria both intercalary and lateral, often form mycelial ring. Thyriothecia orbicular, stellately dehisce at the centre; asci globose, octosporous; ascospores conglobate, brown, uniseptate.

Type species Bheemamyces argyreicola sp. nov.

\section{Bheemamyces argyreicola sp. nov. (Image 1, Figs. 1 \& 2)}

Material examined: 04.xi.2009, on leaves of Argyreia nervosa (Burm. f.) Bojer. (Convolvulaceae), Malabar Botanic Garden, Kozhikode, Kerala, India, coll. A. Sabeena \& M.C Riju, TBGT 4324 (holotype). Isotype is in $\mathrm{HClO}$, New Delhi.

Coloniae epiphyllae, dense vel arte dispersae, ad $2 \mathrm{~mm}$ diam., saepe confluentes. Hyphae bi-typus: subrectae vel anfractuae, irregulariter acuteque vel laxe ramosae, laxe vel arte reticulatae, cellulae 12-32 × 4-5 $\mu \mathrm{m}$. Appressoria dispersa, alternata vel unilateralis, unicellularis, ovata, oblonga, globosa, integra, angularis vel sublobata, 5-17 $\times$ 5-10 $\mu \mathrm{m}$ hyphae secundus exorioratus a hyphae primariae, angustatae, curvulae, leniter elevatae a hostus surfacalis et acutus ad apicem. Appressoria intercalaribus, sub intercalaribus et lateralis. Annulae hyphales irreggularibus

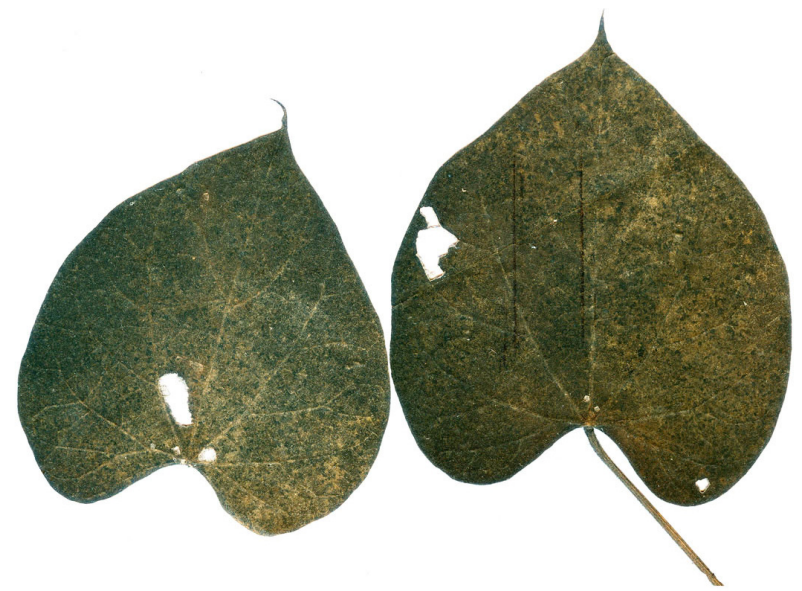

Image 1. Leaves infected with Bheemamyces argyreicola sp. nov. 


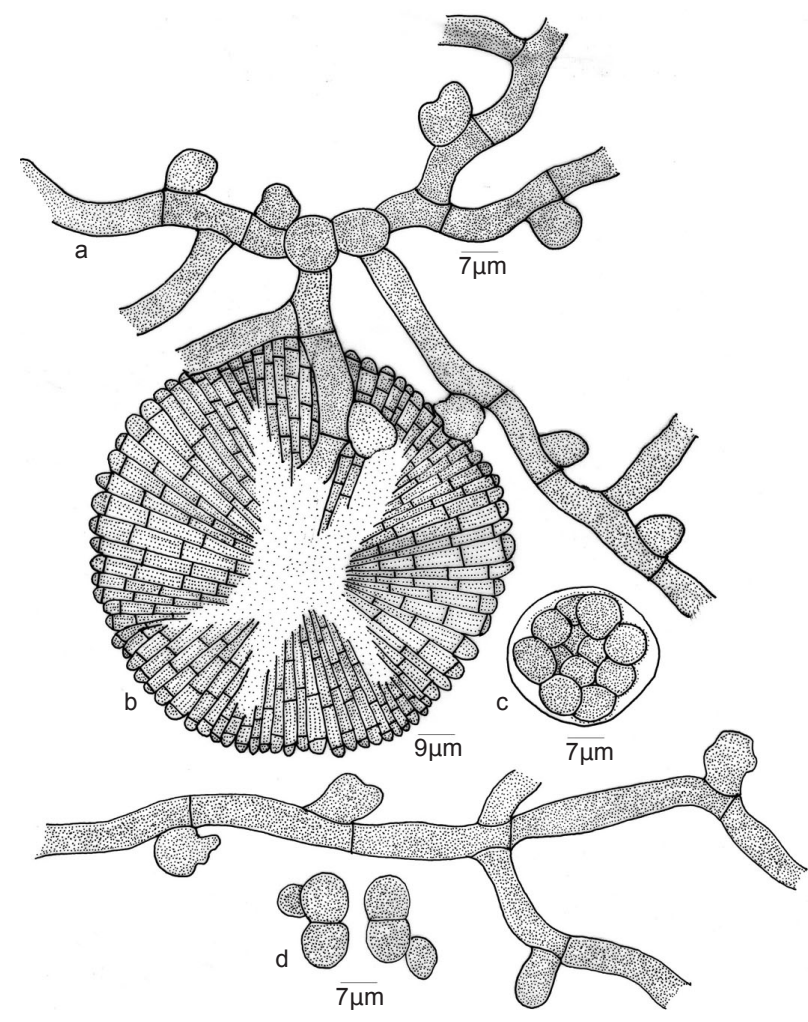

Figure 1. Bheemamyces argyreicola sp. nov. a - Appressoriate mycelium; b - Thyriothecium; c - Ascus; d - Ascospores

et appressoria nulla. Appressoria intercalaria et sub intercalaria, ovala vel globosa, loculum hyalinae ad centre persistantis, 5-10 × 5-7 $\mu \mathrm{m}$. Thyriothecia dispersa vel connata, orbicularis, stellatim dehiscentes ad centre, ad $90 \mu \mathrm{m}$ diam., margine crenatae vel fimbriatae, hyphae fringiorum rectae, flexuosae vel anfractuae; asci globosi, octospori, 32-35 $\mu \mathrm{m}$ diam.; ascosporae brunneae, conglobatae, uniseptatae, constrictus ad septatae, 15-25 $\times$ 7-12 $\mu \mathrm{m}$, parietus glabrus, confestatim germinatae.

Colonies epiphyllous, densely or closely scattered, up to $2 \mathrm{~mm}$ in diameter, often confluent. Hyphae of two types: substraight to crooked, branching irregular at acute to wide angles, loosely to closely reticulate, cells $12-32 \times 4-5 \mu \mathrm{m}$. Appressoria scattered, alternate to unilateral, unicellular, ovate, oblong, globose, entire, angular to sublobate, 5-17 $\times 5-10 \mu \mathrm{m}$. The second type of hyphae originated from the main hyphae, narrower, curved, slightly elevated from the host surface and sharply pointed at the tip. These hyphae possess intercalary, sub intercalary and lateral appressoria. Hyphal rings are formed randomly but are devoid of appressoria. The intercalary and sub intercalary appressoria oval to globose, having a central slightly hyaline spot, 5-10 × 5-7 $\mu \mathrm{m}$. Thyriothecia scattered to connate, orbicular, stellately dehisced at the centre, up to $90 \mu \mathrm{m}$ in diameter, margin crenate to fimbriate, fringed hyphae straight, flexuous to crooked; asci globose, octosporous, 32-35 $\mu \mathrm{m}$ in diameter; ascospores brown,

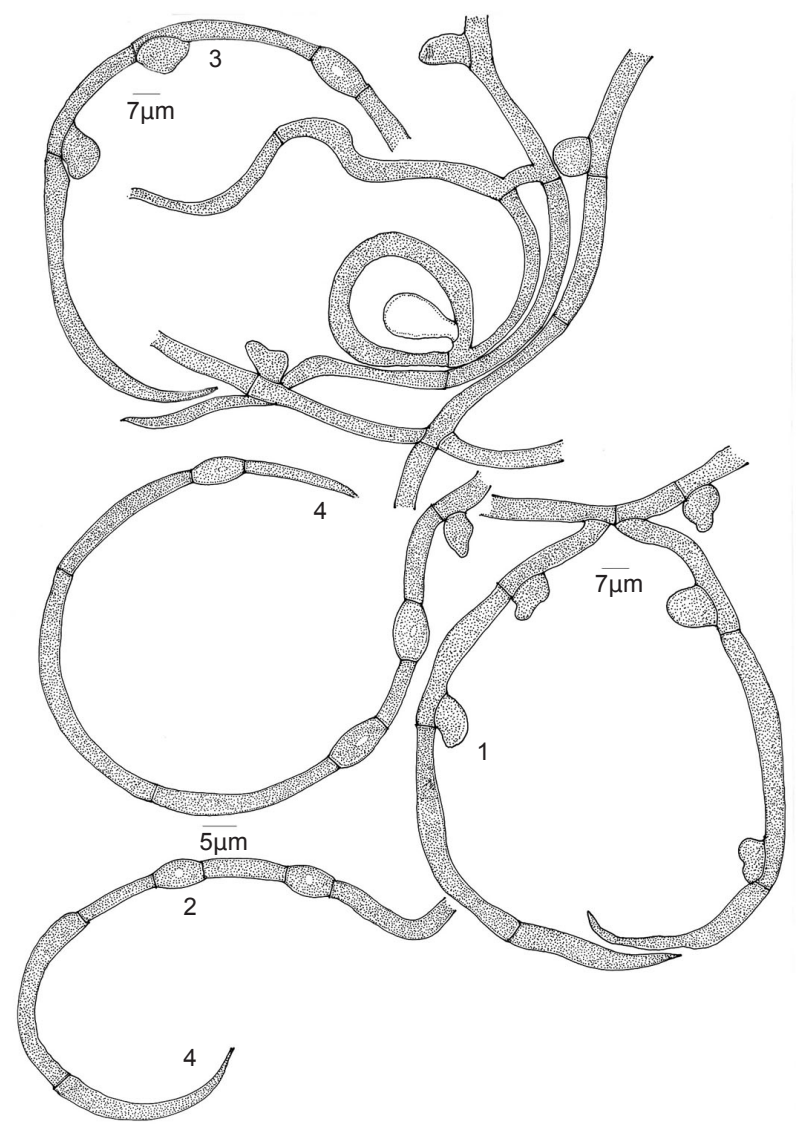

Figure 2. Bheemamyces argyreicola sp. nov. Placement of appressoria: 1 - Lateral; 2 - Intercalary; 3 - Sublateral; 4 - Coiled hyphal tip

conglobate, uniseptate, constricted at the septum, 15-25 $\times$ 7-12 $\mu \mathrm{m}$, wall smooth, readily germinated.

Bheemamyces argyreiae (Hansf.) Hosag., comb. nov. Asterina argyreiae Hansf., Reinwardtia 3: 130, 1954.

Hansford (1954) has also mentioned peculiarity about the appressoria in Asterina argyreiae Hansf. However, the presence of intercalary and sub intercalary appressoria does fit this taxon into the genus Bheemamyces.

\section{REFERENCES}

Arx, J.A.V. \& E. Muller (1975). A re-evaluation of the bitunicate ascomycetes with key to the families and genera. Studies in Mycology 9: 1-159.

Hansford, C.G. (1954). Some Microthyriales and other fungi from Indonesia. Reinwardtia 3: 113-144.

Hosagoudar, V.B., T.K. Abraham \& C.K. Biju (2001). Reevaluation of the family Asterinaceae. J. Mycopathol. Res. 39: 61-63.

Muller, E. \& J.A.V. Arx (1962). Die Gattungen der didymosporen Pyrenomyceten. Beitr. Kryptogamenfl. Schweiz 11: 1-922.

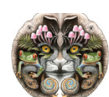

